\title{
Prospecting of Gold Mineralization Indices in the Eastern of Meiganga (Adamawa Region, Cameroon)
}

\section{Bien à Nwos Prisca-Gaëlle1,2*, Kanouo Sylvestre Ngouo ${ }^{3}$, Yongue Fouateu Rose ${ }^{2}$, Toïditan Richard ${ }^{2}$, Keubroh Djitoguem Séverin ${ }^{4}$}

\author{
${ }^{1}$ Institute of Geological and Mining Research, Yaoundé, Cameroon \\ ${ }^{2}$ Department of Earth Sciences, Faculty of Science, University of Yaoundé 1, Yaoundé, Cameroon \\ ${ }^{3}$ Department of Mining Engineering and Mineral Processing, Faculty of Mines and Petroleum Industries, University of Maroua, \\ Maroua, Cameroon \\ ${ }^{4}$ Department of Earth Sciences, Faculty of Science, University of Dschang, Dschang, Cameroon \\ Email: *nwosgaelle@yahoo.com
}

How to cite this paper: Prisca-Gaëlle, B. à N., Ngouo, K.S., Rose, Y.F., Richard, T. and Séverin, K.D. (2021) Prospecting of Gold Mineralization Indices in the Eastern of Meiganga (Adamawa Region, Cameroon). Open Access Library Journal, 8: e7662. https://doi.org/10.4236/oalib.1107662

Received: June 19, 2021

Accepted: July 6, 2021

Published: July 9, 2021

Copyright ( $\odot 2021$ by author(s) and Open Access Library Inc.

This work is licensed under the Creative Commons Attribution International License (CC BY 4.0)

http://creativecommons.org/licenses/by/4.0/

\begin{abstract}
In order to search for secondary gold in the eastern part of Meiganga, alluvial and eluvial field explorations, geological and mineralogical, morphoscopical studies have been carried out in Fell, Gbatoua, and Kombo-Laka. Alluvial and eluvial field explorations have allowed locating six main concentrations points of gold and heavy minerals (olivine, zoïsite, rutile, zircon, ...). Many rocks types are found: volcano-sedimentary (basalts, rhyolites, conglomerates), metamorphic (quartzites, chloritoschists, schists) to deteriorated quartzic and ironic other (consolidated clays). Quartzites are the most represented in the whole area. Alluviums are concentrated in special zones of waterways. One eluvial pit described reveals a sequence of three horizons from the bottom to top: horizon $C$ with residual quartzitic parental rock, a light red (10YR/8/7 to 2.5YR/2/8) horizon B with clays and sands and a yellowish brown $(2.5 \mathrm{YR} / 8 / 6$ to $10 \mathrm{YR} / 8 / 6$ ) horizon A with clays. Grain size distribution of alluvium shows they are globally sandy sediment, with some predominance of gravels and/or coarse sand grains. The "Sorting Index" values show that these sediments are well sorted. The heavy minerals reveal the presence of zircon, zoïsite, magnetite, hematite, ilménite and opaque minerals. Statistics studies done on these minerals show a predominance of opaque minerals and zoïsite. Gold grains have been found in the top of horizon $\mathrm{C}$ and in the banks of Fel, Bandoungui, Sokour, Mifek and Wan Toro waterways. Their morphoscopical study shows mainly shiny sub-blunt with some shiny sub-angular and blunt grains. Their forms are nuggets, powders and dusts. Any form characterizes a locality. The
\end{abstract}


mineralogical results obtained suggest that these mineralized sediments have a multiple origin source, which is supposed to be determined.

\section{Subject Areas}

Metal Material

\section{Keywords}

Meiganga-East, Placer, Heavy Minerals, Gold

\section{Introduction}

Mineral prospecting is a systematic search undertaken through different methods or techniques to discover potential natural resources in a locality [1]. This applied geology consists of the research, discovery and development of anomalies. The methodology varies according to the useful element sought, in particular for the present case of gold. Gold is a precious and siderophilic metal generally present in very low concentrations in the rocks of the earth's continental crust, only $4 \mathrm{ppb}$ with the continental crust having $1.3 \mathrm{ppb}$ [2]. Metallogenic processes that lead to the formation of economically exploitable deposits, mainly through hydrothermal circulation, can reach enrichment rates of the order of 10,000 [3] [4] [5]. The classification of gold deposits is complex, but the knowledge gained on the main types allows the development of guides for their research [1] [5].

In humid tropics, mining exploration is severely hampered by the existence of a thick soil cover which prevents, outside the river system and steep areas, any direct examination of outcrops [6]. In Cameroon, two types of. known deposits are registered such as the placer gold and the lode gold [7] [8] and occur mainly in eastern (Eastern Auriferous Zone) [9] and northern (Northern Auriferous Zone) [10] regions to south-Western Chad [11]. Gold has been mined from placer gold deposits up and down and in different types of environment. Initially, rich, easily discovered, surface and river placers were artisanally exploited [12] with mining focused on alluvial, eluvial deposits and weathered quartz veins. Over the last few decades, small-scale gold mining became an important source of income for rural communities and drives economic development [13] [14].

In Meiganga-East, artisanal mining has been ongoing in a number of localities notably Fell, Wan Tia and Kombo Laka, in Adamawa Cameroon; but no major study has been carried out and literature on gold mineralization in that part of the country is scarce except ongoing exploration work by gold exploration companies such as Southland Mining Cameroon, Harvest Mining Corporation [15]. The present study is a preliminary descriptive. It will contribute to defining the conditions of sedimentation, lithological setting, particle size, aspect ratio of pebbles from the gold indices and finally the gold grains count in different 
stream and horizon in view to optimize the gold extraction from sediments. These may serve as a basis for gold exploration and recovery within Meiganga-East especially in geology, petrology and mineralogy.

\section{Geologic Setting}

The granito-gneissic plateau of the Adamaoua (Figure 1(a)) includes lateritic surface formations [16], volcanic cover formations [17] [18] covering the northern cliff of the Mbéré and in small quantities south of the Mbéré Djerem line, and sedimentary formations [19] [20] [21] resting unconformably on old basement; old basement formations [22] [23] outcropping to the north and east of the Ngaoundéré-Belel basaltic cover and including micaceous quartzites, embreccities, anatexites, granitic massifs [23] [24] [25] [26].

The Meiganga Plateau (Figure 1(b) and Figure 1(c)) is part of the Central Cameroonian domain [27] [28] which is also called the Adamawa-Yade domain (AYD), which stretches from southern Bafia to northern Central African Republic and from southern Poli to southern Chad. It contains syntectonic, tarditectonic, post-tectonic and orthogneissified granitoids with hyperpotassic to aluminous tendencies [24] [29] and formations dated to about $2.1 \mathrm{Ga}$ by U-Pb/Zr [30]. These granitoids include biotite-muscovite granite and pyroxene-amphibole-biotite granite [26]. The Central Cameroon domain has been affected by major tectonic

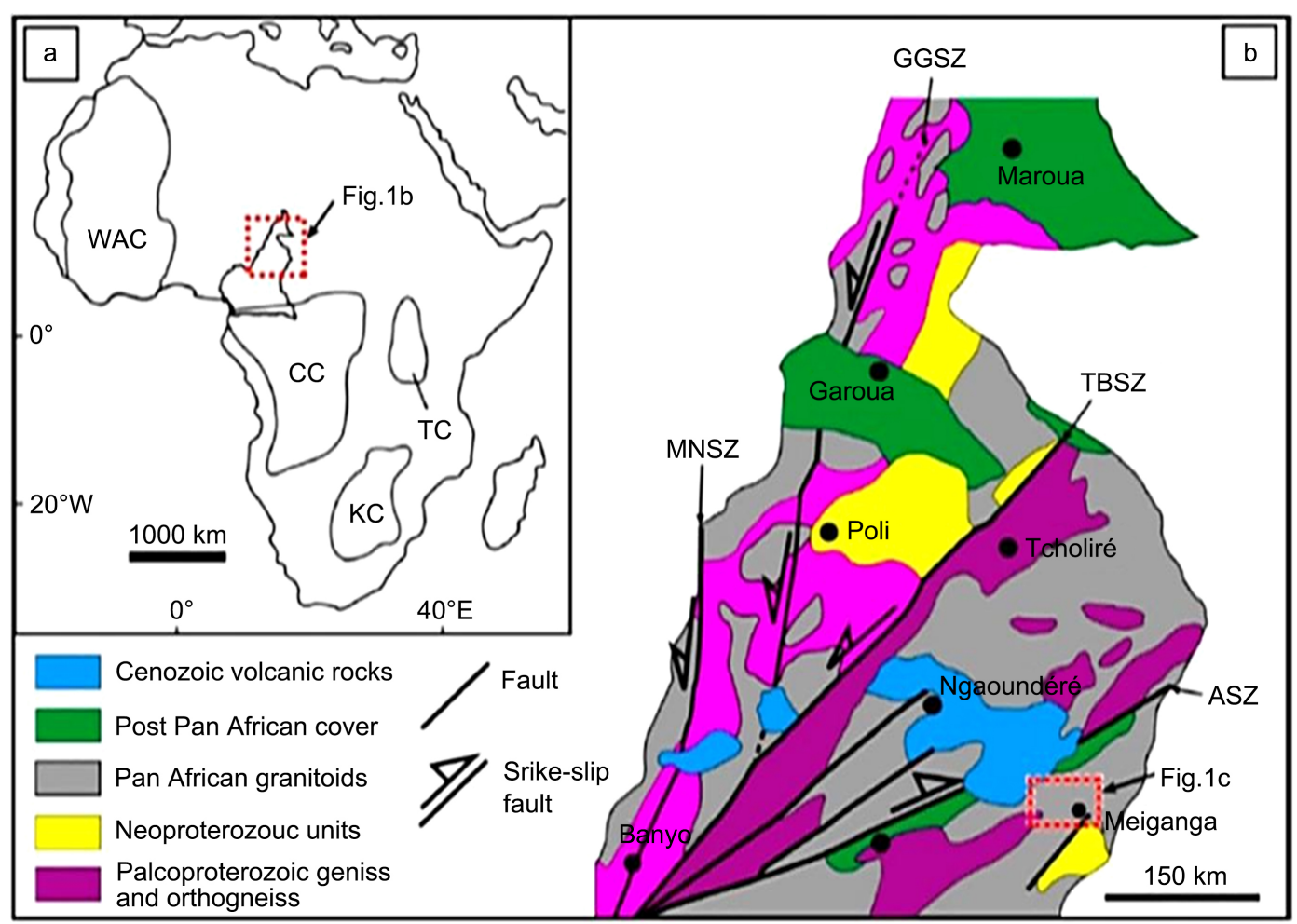

Figure 1. (a) Location of Cameroon in Africa, WAC: West African Craton; CC: Congo Craton; TC: Tanzanian Craton; KC: Kalahari Craton; (b) Geological sketch map of northern part of Cameroon showing from the major lithotectonic domains [29] [34]; (c) Study area; MNZ: Mayo Nolti shear zone; TBSZ: Tcholiré-Banyo Shear Zone; ASZ: Adamaoua shear zone. 
accidents including the Central Cameroon Shear, a ductile accident and the Sanaga Fault, a brittle accident [31] [32]. The Pan-African mobile zone is 500 - 600 $\mathrm{Ma}$ in age [33]. The Lom series dated $700 \mathrm{Ma}$ is part of this ensemble which is interpreted as a substratum of Archean to Palaeoproterozoic age dismantled during the Pan-African orogeny and intruded by Pan-African batholiths [24] [26].

The Meiganga area (Figure 2) is located between two important faults: the Adamaoua fault and the Betaré-Oya fault [35]. The work carried out in the Adamaoua region and specifically in Meiganga-East focused solely on the petrographic, structural and environmental studies [23] [26] [35] [36].

\section{Methodology}

\subsection{Field Study}

Field study was done with the aid of standard field equipments. Hammer prospection aided in identifying the various rock types in the area. At each location the various rock types observed were systematically described using observable field parameters (color, mineralogy and structure) and sampled. 3 mounts were prospected: Fell, Ka'awang and Mboum. One eluvial pit was also dug at shallow depth (about $3 \mathrm{~m}$ ) due to the intense artisanal activity. The horizons were described and 20 liters of eluvium obtained and panned in nearby streams to obtain the concentrate.

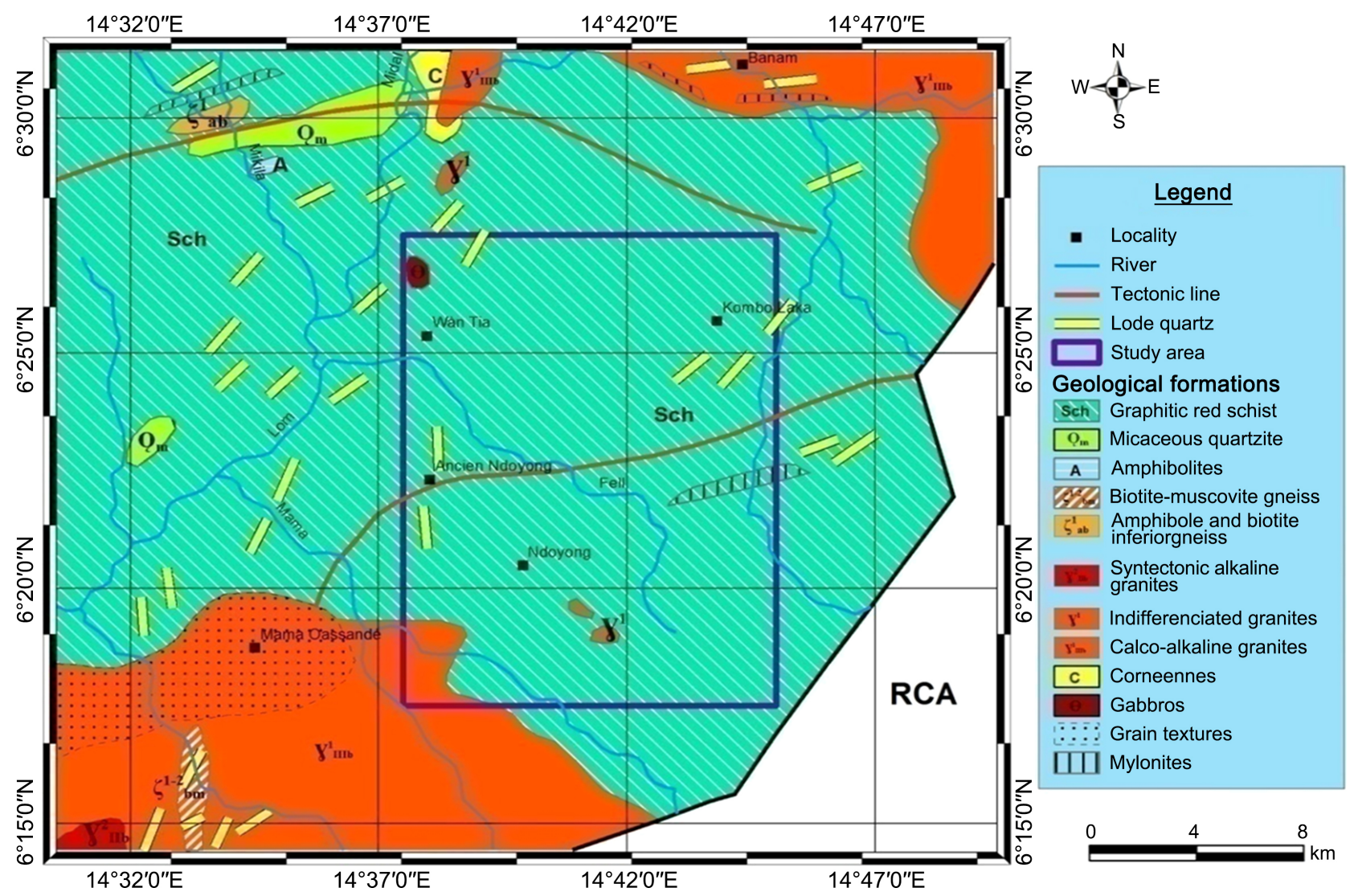

Figure 2. Geological map of the study area; modified from Ganwa et al. 2004 [24]. 
Alluvial prospection in the various stream in the locality was also carried out. This involved collection of sediments at points of optimal mineral concentration such as confluence points, along meanders and rocky portions of the streams. Unwashed gravel samples were collected for laboratory analysis. Of the washed fraction, the heavy minerals were retained. The methods and techniques used in sampling and settling were those of [1]. In each river, 40 liters of gravel was measured and 20 liters was panned to obtain the concentrate. Sampling points for eluvium and alluvium are shown.

\subsection{Petrographic Study}

Petrographic study involves the macroscopic, microscopic and mineralogical description on the field and in the laboratory respectively. Macroscopic observation starts on the field whereby, the different rock samples collected from various outcrops were observed with the naked eye. Microscopic observation of rock thin sections was carried out under a light microscope. Mineralogical analyses released the analyses of SEM (scanning electron microscope), XRD (Xray diffractogram) and IRD (Infrared diffractogram) of one rock in the area.

The measuring instruments are respectively a BRUKER ASX D8 Advance diffractometer and a Brucker IFS55 Fourier Transform IR spectrometer with a frequency $4000 \leq \lambda^{-1} \leq 600$ cc's.

The petrography of heavy minerals obtained from eluvial and alluvial prospection was equally done in the laboratory. The aim of this was to identify the various heavy minerals associated to the gold mineralisation and also to see whether they reflect the mineral composition of rocks in the study zone. In order to mount heavy mineral thin sections, a sieve analyses was carried out on the mineral concentrates as follows. They were separated according to their grain size in a column of AFNOR sifters (diameters ranging from $0.08 \mathrm{~mm}$ to 0.315 $\mathrm{mm}$ ). After the grain size separation of the concentrates, those with diameter between $0.125 \mathrm{~mm}$ to $0.250 \mathrm{~mm}$ were used to preparate thin sections before being identified under a polarizing microscope. Heavy minerals of the $0.125 \mathrm{~mm}$ to $0.250 \mathrm{~mm}$ phase were separated from lighter ones by pouring the concentrate in bromoform (density $>2.89$ ) using a separating funnel. Magnetic minerals were later hand-picked with a magnet. The heavy minerals collected were washed with $95 \%$ alcohol to wash bromoform and then with $10 \%$ hydrochloric acid for about 20 minutes, in order to eliminate the iron oxide film.

\subsection{Morphoscopic Study}

This study was done with the aid of a binocular magnifying glass of JENA type. The purpose of this study was to describe the length, the shape and surfaces of the gold grains recovered from each heavy mineral concentrate sample, using the terminology employed by [37] in describing sediments. A total of 55 gold grains were collected after washing 40 liters of alluvium collected in each river along Fel, Sokour, Mifek, Wan Toro streams; and 20 liters of eluvium of horizon C. 
Heavy minerals are also studied. The fractions $0.315 \mathrm{~mm}$ and [0.250 $-0.125 \mathrm{~mm}$ ] are described. The techniques and qualification methods used are those recommended by [38] [39].

\subsection{Evaluation of Content}

It aims at calculating the gold grade in the gravel and horizon $\mathrm{C}$, depending to the number of pans of gravel washed and the weight of gold grains from each prospection point. The gold grade in gravel (tgr), is the grade obtained in $1 \mathrm{~m}^{3}$ of gravel and is given by the relation: $\operatorname{tgr}=\mathrm{W} \times \mathrm{N} / \mathrm{n}$.

The gold grade in a square meter of the gravel (tc) is the product of the gold grade in the gravel by the thickness of gravel: $t c=\operatorname{tgr} \times \mathbf{g}$.

The gold grade in the excavated material in cubic meter (te) is that obtained in $1 \mathrm{~m}^{2}$ of the whole column and is given by the relation: te $=\mathrm{tc} /(\mathrm{g}+\mathrm{s})$.

$\mathrm{n}$ : number of pans washed, $\mathrm{N}$ : number of pans in meter cube, $\mathrm{W}$ : weight of the grains collected in the alluvium, g: thickness of the gravel, s: thickness of the barren material, $\mathrm{H}$ : total thickness of the alluvium.

\section{Results}

\subsection{Petrography}

\subsubsection{Polarizing Microscope}

The names of the minerals and rocks (Figure 3 ) are given on the basis of work carried out by [40]. The olivine basalt is located at the top of Mount Fell and occurs in metric to centimetric blocks (Figure 3(a)). The rock has a porphyritic microlitic microstructure (Figure $3(\mathrm{~b})$ ) and contains feldspar (10\%), clinopyroxene $(41 \%)$, olivine (30\%), plagioclases (10\%) and opaque minerals $(5 \%)$.

The rhyolite is at the foot of Mount Fell and is in the form of domes and embankments (Figure 3(c)) set under the Fel stream. The rock has a porphyritic to fluidic residual microstructure (Figure 3(d)) and contains quartz (35\%), plagioclases (25\%), sanidine (25\%), biotite (8\%) and chlorite (2\%).

The conglomerate is located at the foot of Mount Mboum; this massive deposit is arranged obliquely on the banks (Figure 3(e)) of the Sabi river. The rock has a heteroganular coarse microstructure. The lithic elements and minerals are embedded in a ferruginous to clay-iron cement. Quartz is the only pebble observed (85\%). The matrix occupies an estimated 15\% (Figure 3(f)).

The quartzite is located at the foot of Mount Fell in massive rocks ranging in thickness from 0.3 to $40 \mathrm{~m}$. They are highly fragmented into decametric blocks with millimetre-sized quartz veinlets (Figure 3(g)). It has a heteroganular granoblastic microstructure and includes quartz (78\%) and orthostone (22\%) microphenocrystals (Figure 3(h)).

The Chlorite Schist is located south of Mount Fell and occurs as a high-powered N040E vein (Figure 3(i)). It is buried under a thick lateritic layer of about 3 meters. It has a granolepidoblastic (Figure $3(\mathfrak{j})$ ) non-oriented granolepidoblastic microstructure of quartz (42\%), pyroxenes (18\%), chlorite (35\%) and epidote (5\%). 
Schist bedded quartzite is localized at Fell and Mboum Mountains and is hosted in massive, banded-structured flying blocks (Figure $3(\mathrm{k})$ ). The schist bed has a lepidoblastic microstructure with sericite (42\%) and quartz (8\%). The quartz bed has a heterogranular granoblastic microstructure (Figure 3(1)) consisting of quartz (42\%), sericite (8\%), and opaque minerals (3\%).

Ferruginous argillite (Red Quartzite) is located at the foot of Mount Mboum. The outcrop is located under a stream (Figure $3(\mathrm{~m})$ ). It is highly fractured and in the form of centimetric blocks. It has a fine heteroganular clastic microstructure (Figure $3(n)$ ) consisting of quartz (56\%), iron cement (42\%) and muscovite $(2 \%)$.
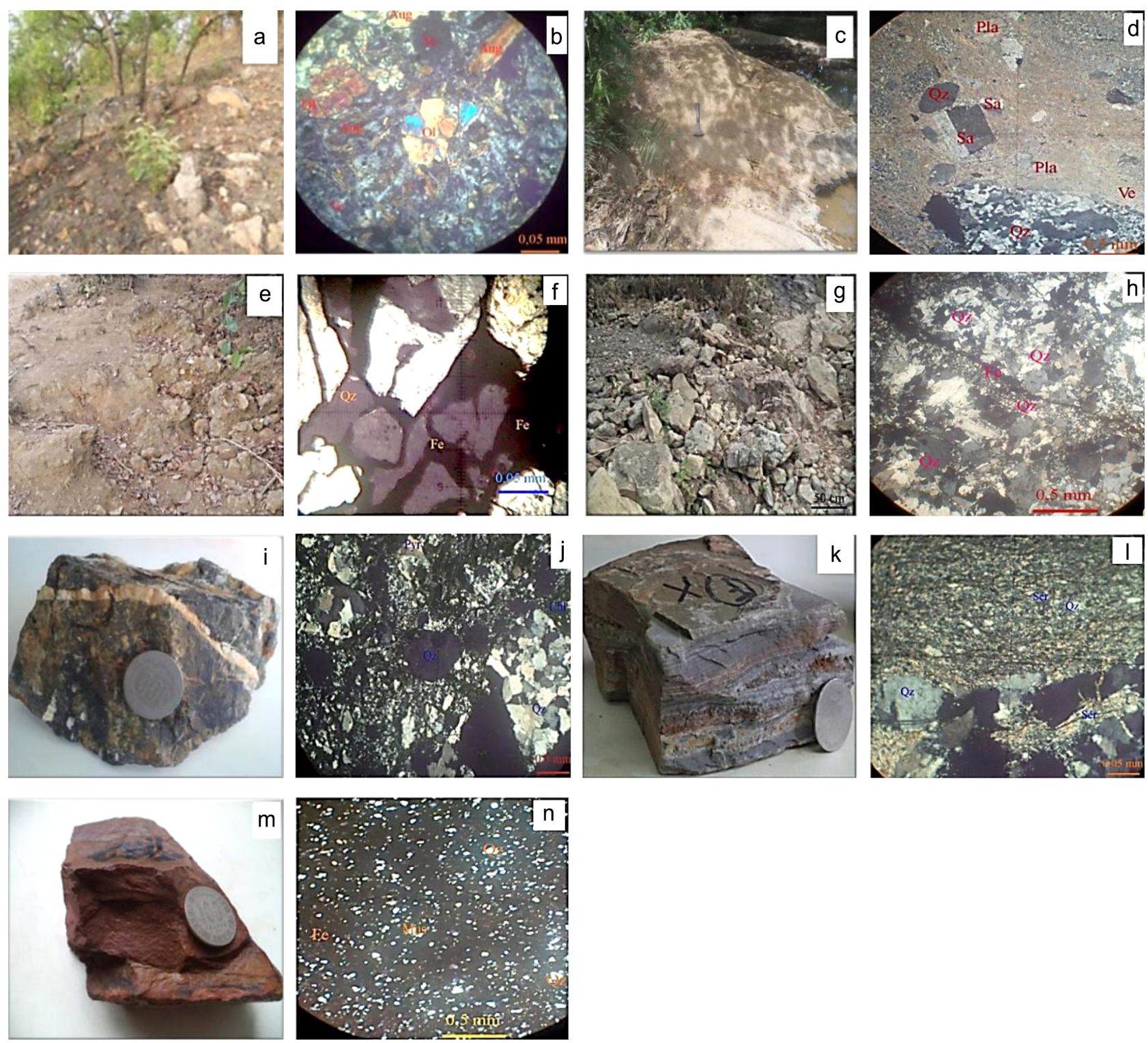

Figure 3. Petrographic study with polarizing microscope. (a) Olivine basalt residual outcrop; (b) Olivine basalt; (c) Rhyolite outcrop; (d) Rhyolite; (e) Conglomerate; (f) Conglomerate basin; (g) Quartzite outcrop; (h) Quartzite; (i) Chloritoschist sample; (j) Chloritoschist; (k) Schist sample; (l) Schist; (m) Iron argilite sample; (n) Iron argilite. Abbreviations: ol = olivine, aug = augite, ve = verre, $\mathrm{sa}=$ sanidine, $\mathrm{qz}=$ quartz, pla = plagioclase, $\mathrm{fe}=$ fer, $\mathrm{chl}=$ chlorite, ser $=$ séricite, mus $=$ muscovite. 


\subsubsection{SEM (Scanning Electron Microscope), Xray Diffractogram (XRD) and Infrared Diffractogram (IRD)}

The quartz argilite at Mount Ka'awang is placed on a bank (Figure 4(a) and Figure 4(b)). It is characterized by high friability. The variation in colour (light grey "10YR8/1" and Belgian " $5 \mathrm{Y} 8 / 4$ ") is due to variable iron oxide and/or titanium oxide contents.

1) Scanning electron microscope (SEM)

This 3D characterization shows illite, kaolinite, quartz, anatase and ferric oxides (Figure $4(\mathrm{c})$ ).

2) X-ray diffractogram

The stripping (Figure 5) shows the presence of clay minerals (kaolinite, illite) and non-clay minerals (quartz, feldspar, maghemite, anatase, ilmenite and zircon) (Table 1) and the frequency of elements (Table 2).

3) Infrared diffractogram

The IR spectrum of the material has three main groups of absorption bands (Figure 6).

Between 3800 and $3500 \mathrm{~cm}^{-1}$, the valence of the $\mathrm{O}-\mathrm{H}$ bond of kaolinite vibrates. One of the four $\mathrm{OH}$ of the half-mesh on the inner layer is responsible for absorption around $3620 \mathrm{~cm}^{-1}$ [41]. The other three hydroxyles are on the outer layer. Of these three -OHs, two are approximately perpendicular to the leaflet and the third makes an angle of $14^{\circ}$ with the plane of the leaflet. The latter hydroxyl is responsible for absorption around $3653 \mathrm{~cm}^{-1}$ [41]. The coupling between the other two hydroxyles results in the presence of absorptions around 3692 and $3678 \mathrm{~cm}^{-1}$. The $\mathrm{OH}$ band of illite also appears around $3620 \mathrm{~cm}^{-1}$ [41].

Between 1150 and $900 \mathrm{~cm}^{-1}$, the vibration bands of the Si-O bonds generally observed in silicates appear [42]. It is in this same zone that the vibration bands of quartz appear. The vibration bands of $\mathrm{O}-\mathrm{Al}-\mathrm{OH}$ bonds are also found there.
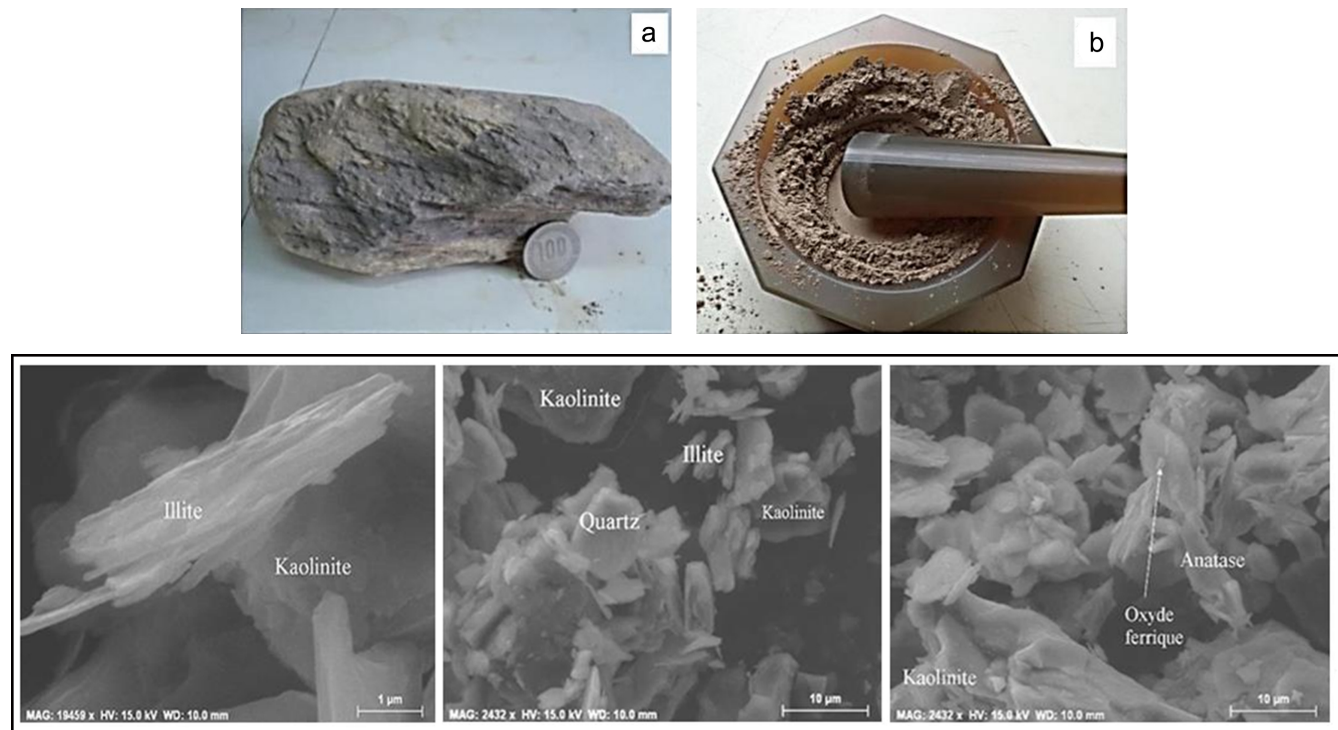

(c)

Figure 4. Petrographic study with scanning electron microscope (SEM). (a) Quartz argillite; (b) Quartz argilite powder; (c) Microphotographs of powder (Kaolinite, Illite, Quartz, Anatase, Ferric oxide). 


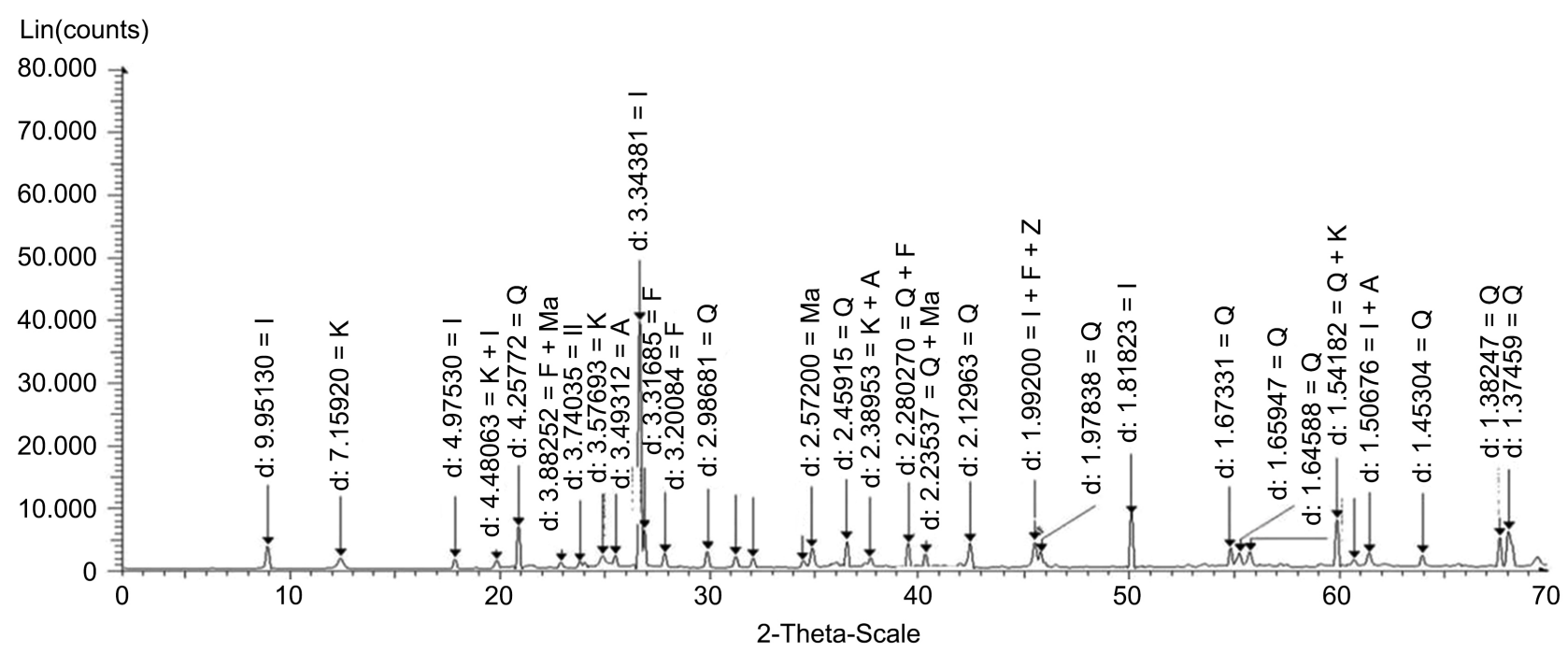

Type: locked coupled - start $2.000^{\circ}$ - End: $69,998^{\circ}$ - step: 0.021 - step time: $48 \mathrm{~s}$ - Temp: $25^{\circ} \mathrm{C}$ (Room) - Time started: $0 \mathrm{~s}$ - 2 Theta: $2.000^{\circ}$ - Theta: $1.000^{\circ}$ - Chi: $0.00^{\circ}$ - Phi: $0.00^{\circ}$ - operation smooth $0.150 /$ Fourier: $20.000 \times 1 /$ Strip Kalpha $20.500 /$ Import

Figure 5. Petrographic study with XR diffractogramm (XRD). Abbreviations: $\mathrm{K}=$ kaolinite, $\mathrm{I}=\mathrm{illite}, \mathrm{Q}=\mathrm{quartz}, \mathrm{F}=$ feldspath, $\mathrm{Ma}=$ maghémite, $\mathrm{A}=$ anatase, $\mathrm{Il}=$ ilménite, $\mathrm{Z}=$ zircon.

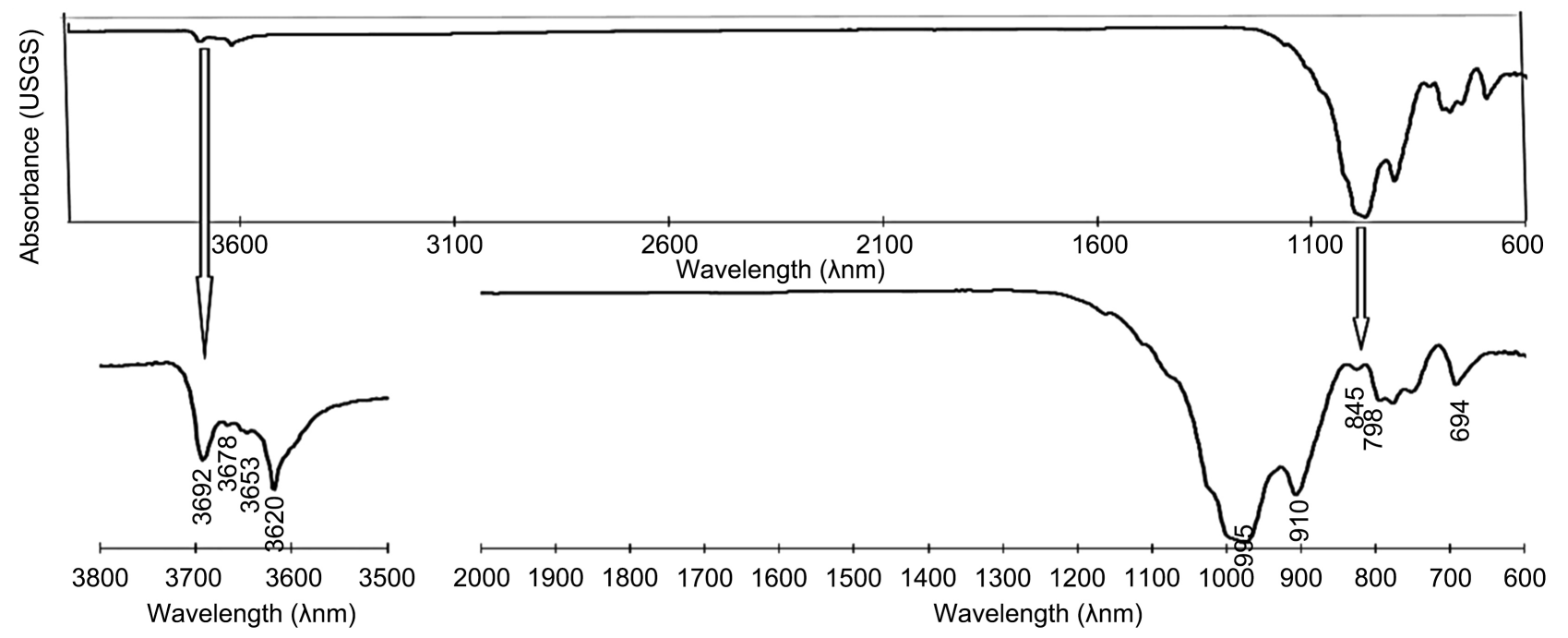

Figure 6. Petrographic study with Infrared (IR).

Table 1. Mineral species of quartz argillite.

\begin{tabular}{cccc}
\hline Minerals & Chemical formula & $\begin{array}{c}\text { Some lines observed on } \\
\text { diffractogram }(\AA)\end{array}$ & $\begin{array}{c}\text { Corresponding dhkl on } \\
\text { A.S.T.M. files }\end{array}$ \\
\hline Kaolinite & $\mathrm{Si}_{2} \mathrm{O}_{5} \mathrm{Al}_{2}(\mathrm{OH})_{4}$ & $7.15 ; 3.57 ; 1.54$ & $7.17 ; 3.57 ; 1.545$ \\
Illite & $\mathrm{K}\left[\left(\mathrm{Si}_{3} \mathrm{Al}_{\mathrm{O}} \mathrm{O}_{10} \mathrm{Al}_{2}(\mathrm{OH})_{2}\right]\right.$ & $9.95 ; 4.97 ; 1.99$ & $10.00 ; 5.02 ; 2.005$ \\
Quartz & $\mathrm{SiO}_{2}$ & $4.25 ; 3.34 ; 1.81$ & $4.26 ; 3.34 ; 1.817$ \\
Feldspath & {$[(\mathrm{K}, \mathrm{Na})$ ou $(\mathrm{Ca}, \mathrm{Na})] \mathrm{Si}_{3} \mathrm{AlO}_{8}$} & $3.88 ; 3.31 ; 3.20$ & $3.83 ; 3.31 ; 3.21$ \\
Maghémite & $\mathrm{Fe}_{2} \mathrm{O}_{3}$ & $3.88 ; 2.57 ; 2.23$ & $3.86 ; 2.52 ; 2.234$ \\
Anatase & $\mathrm{TiO}_{2}$ & $2.38 ; 1.50$ & $2.379 ; 1.494$ \\
Ilménite & $\mathrm{FeTiO}_{3}$ & 3.74 & 3.734 \\
Zircon & $\mathrm{ZrSiO}_{4}$ & 1.99 & 2.06 \\
\hline
\end{tabular}


Table 2. Frequency of the elements of the total powder diffraction mineralogical procession.

\begin{tabular}{|c|c|c|c|c|c|c|c|c|c|}
\hline \multicolumn{10}{|c|}{ XR diffraction on rock mass } \\
\hline \multirow{2}{*}{ Facies type } & \multirow{2}{*}{ Number of sample } & \multicolumn{8}{|c|}{ Mineral species } \\
\hline & & Q & $\mathrm{F}$ & $\mathrm{Ma}$ & A & Il & $\mathrm{K}$ & I & $\mathrm{Z}$ \\
\hline Quartz argillite & LaW 0402 & ++++++++ & ++ & ++ & ++ & + & ++ & ++++ & + \\
\hline
\end{tabular}

Between 900 and $650 \mathrm{~cm}^{-1}$, deformation bands of the O-H bonds appear [41] [42]. The band around $750 \mathrm{~cm}^{-1}$ coupled with that of $3620 \mathrm{~cm}^{-1}$ indicates the presence of illite in these clay materials [41]. This indicates that kaolinite is the main constituent. It is associated with illite and quartz.

\subsection{Eluvium}

Eluvial study at Fell enabled the identification of three soil horizons; horizon C with residual quartz parent rock, horizon B sandy-clay with light red armour nodules $(10 \mathrm{YR} / 8 / 7$ to $2.5 \mathrm{YR} / 2 / 8)$ with $5.4 \mathrm{~m}$ and horizon A clayey yellow-brown $(2.5 \mathrm{YR} / 8 / 6$ to $10 \mathrm{YR} / 8 / 6)$ with $40 \mathrm{~cm}$. The gold index (sample WAN 1) was in horizon C (Figure 7).

\subsection{Alluvium}

An alluvial pit study at Fell enabled the identification of three horizons. Horizon C with residual quartz parent rock and sand, grayish black (7.5RP/4/1) with 190 $\mathrm{cm}$. Horizon B with sandy clay with grayish red armour nodules $(2.5 \mathrm{YR} / 5 / 8$ to $2.5 \mathrm{YR} / 3 / 8)$ with $170 \mathrm{~cm}$. Horizon A with clayey sand, gray to dark gray (7.5YR/6/2 to $7.5 Y R / 2 / 1$ ) nodule, with $140 \mathrm{~cm}$ (Figure 8).

Alluvial prospection enabled the locations of gold indices in five rivers: Fel, Aigbatoua, Sokour, Mifek and Wantoro (Figure 9). The orientation of lineament is NE-SW and NW-SE.

\subsection{Heavy Mineral Assemblage}

\subsubsection{Polarizing Microscope}

Heavy mineral assemblage in alluvium and eluvium include monazite, sphene, sillimanite, muscovite, rutile, zoïsite, zircon, opaque minerals. Microphotographs of heavy minerals are shown in Figure 10.

\subsubsection{Using a Binocular Magnifying Glass}

Heavy mineral assemblage in alluvium and eluvium include olivine, disthene, zircon, rutile, tourmaline, magnetite, ilmenite, hematite. Microphotographs of heavy minerals are shown in Figure 11.

\subsection{Gold Morphoscopy}

The morphoscopy of gold grains from each prospection pit shows that they are generally irregular in shape (Figure 12). 

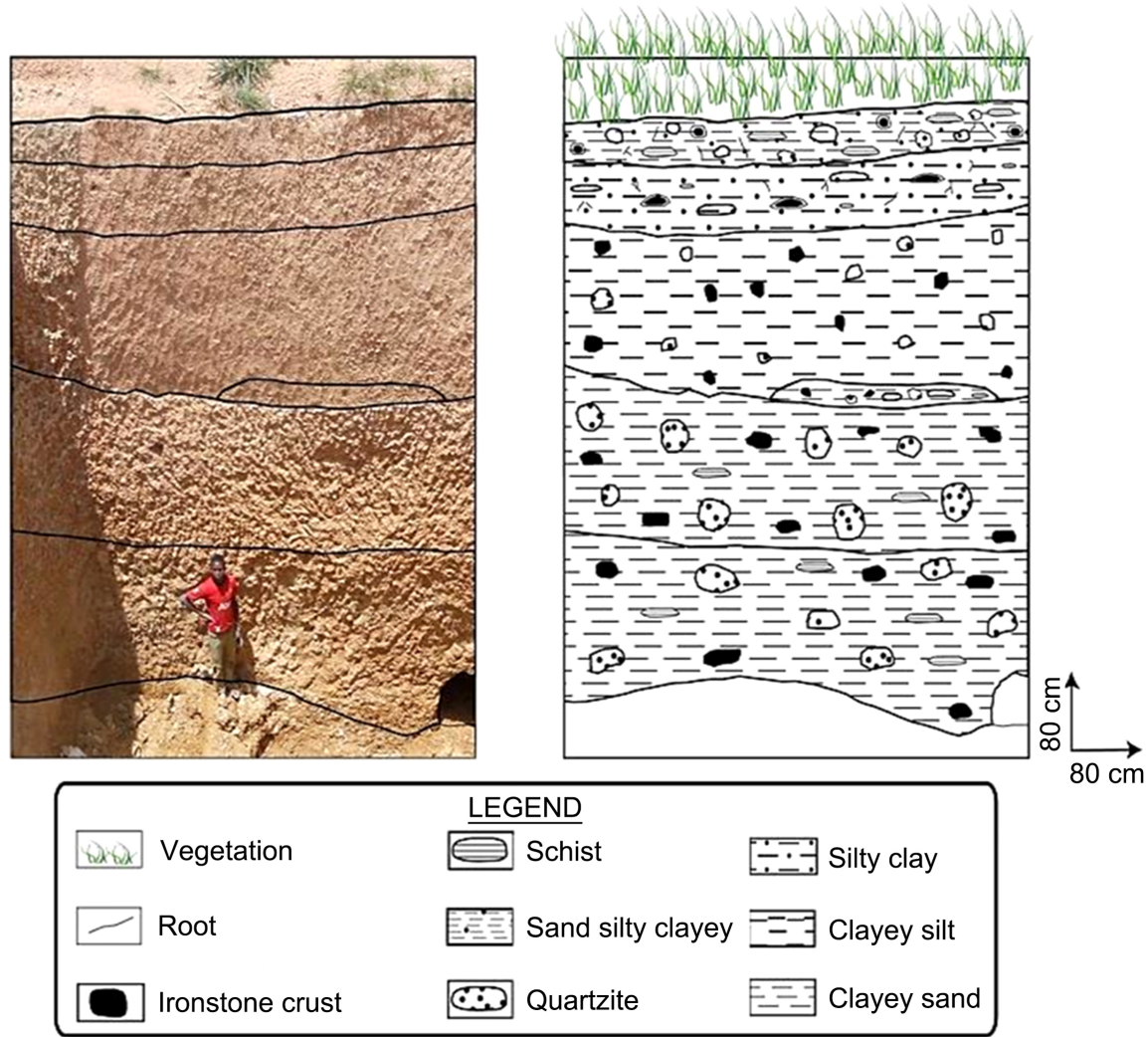

Figure 7. Eluvium pit in WanTia.
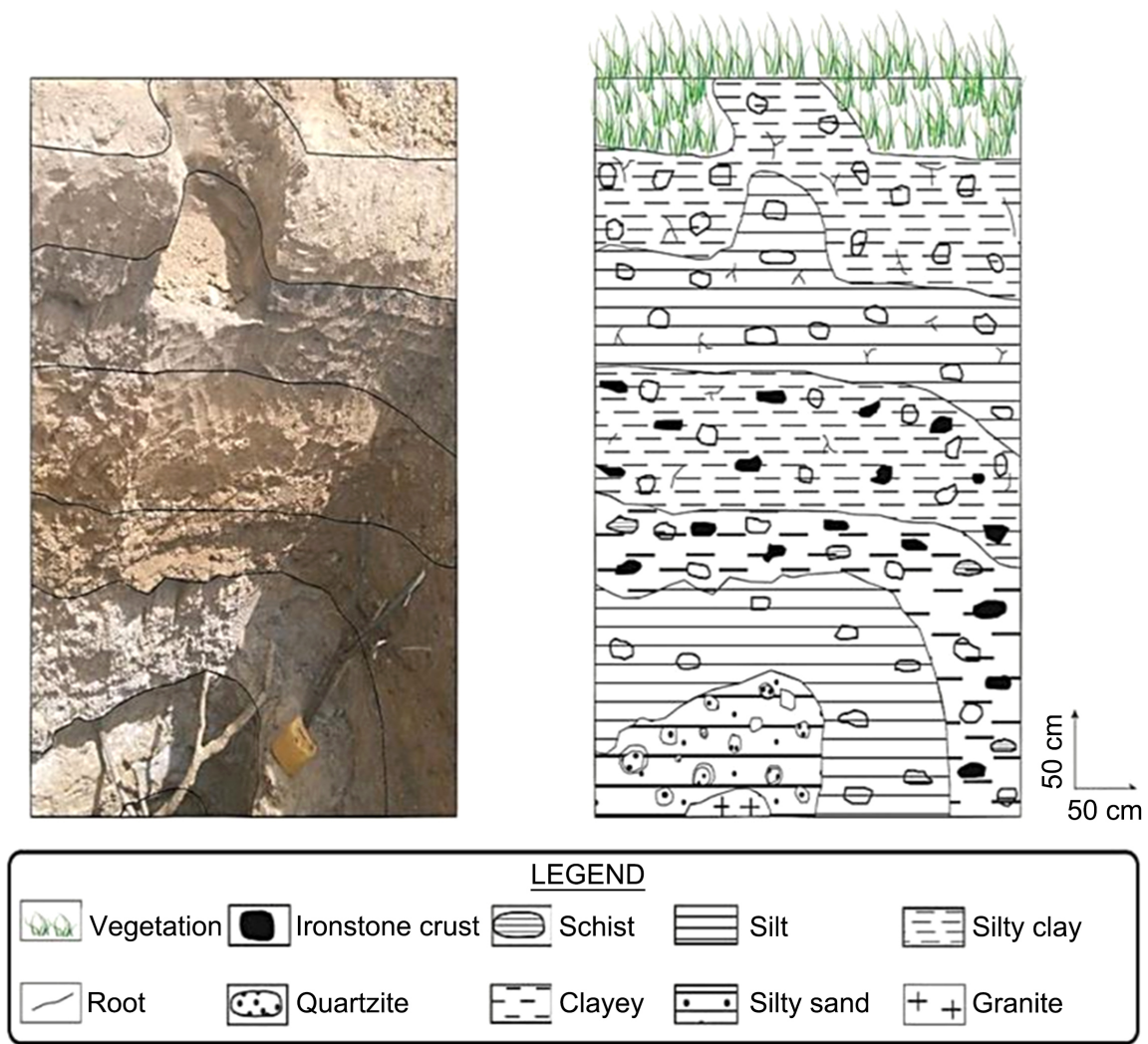

Figure 8. Sketch map of alluvial pit (gold indice of WanTia). 

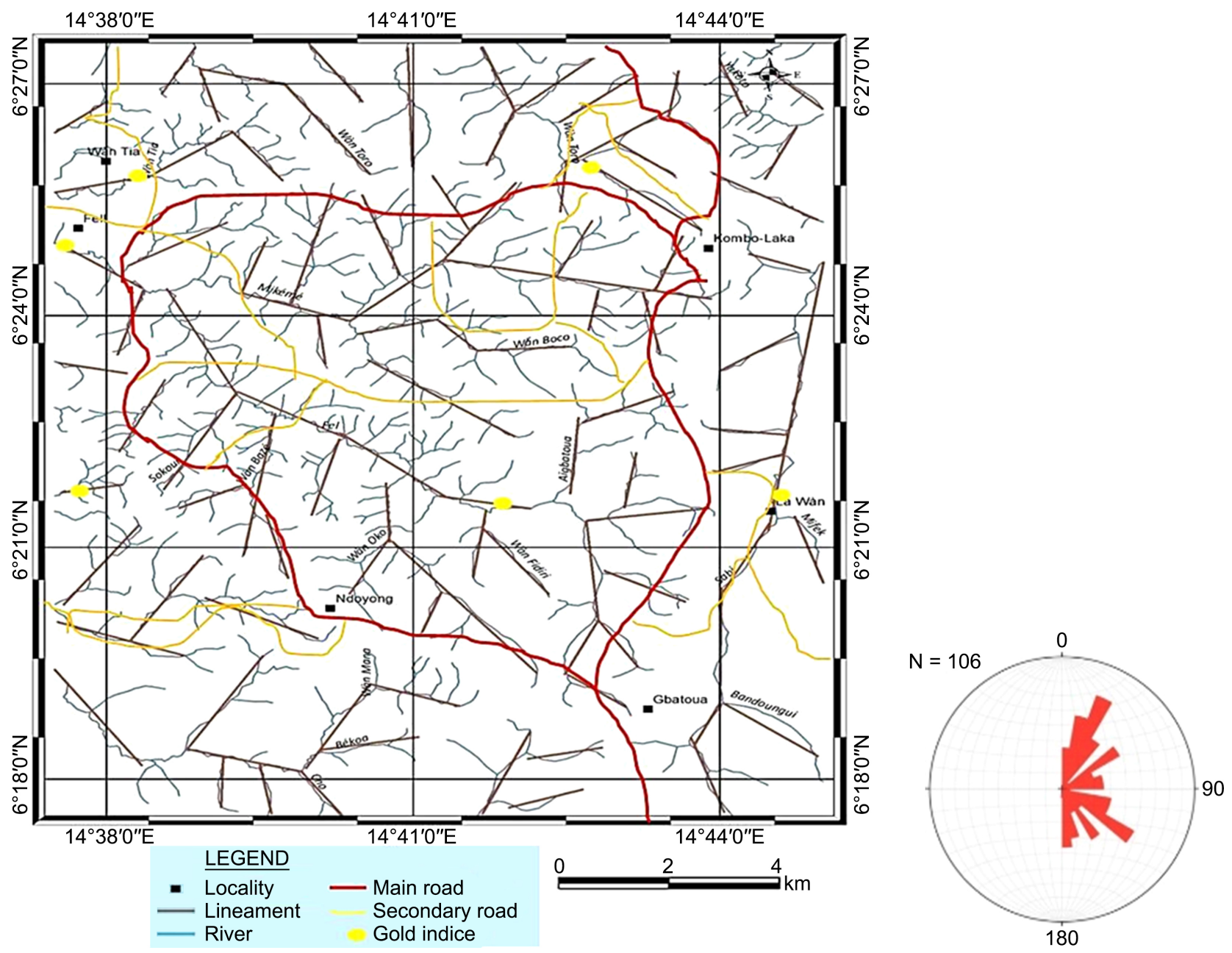

Figure 9. Gold alluvial sediments in stream with orientation of the lineaments.
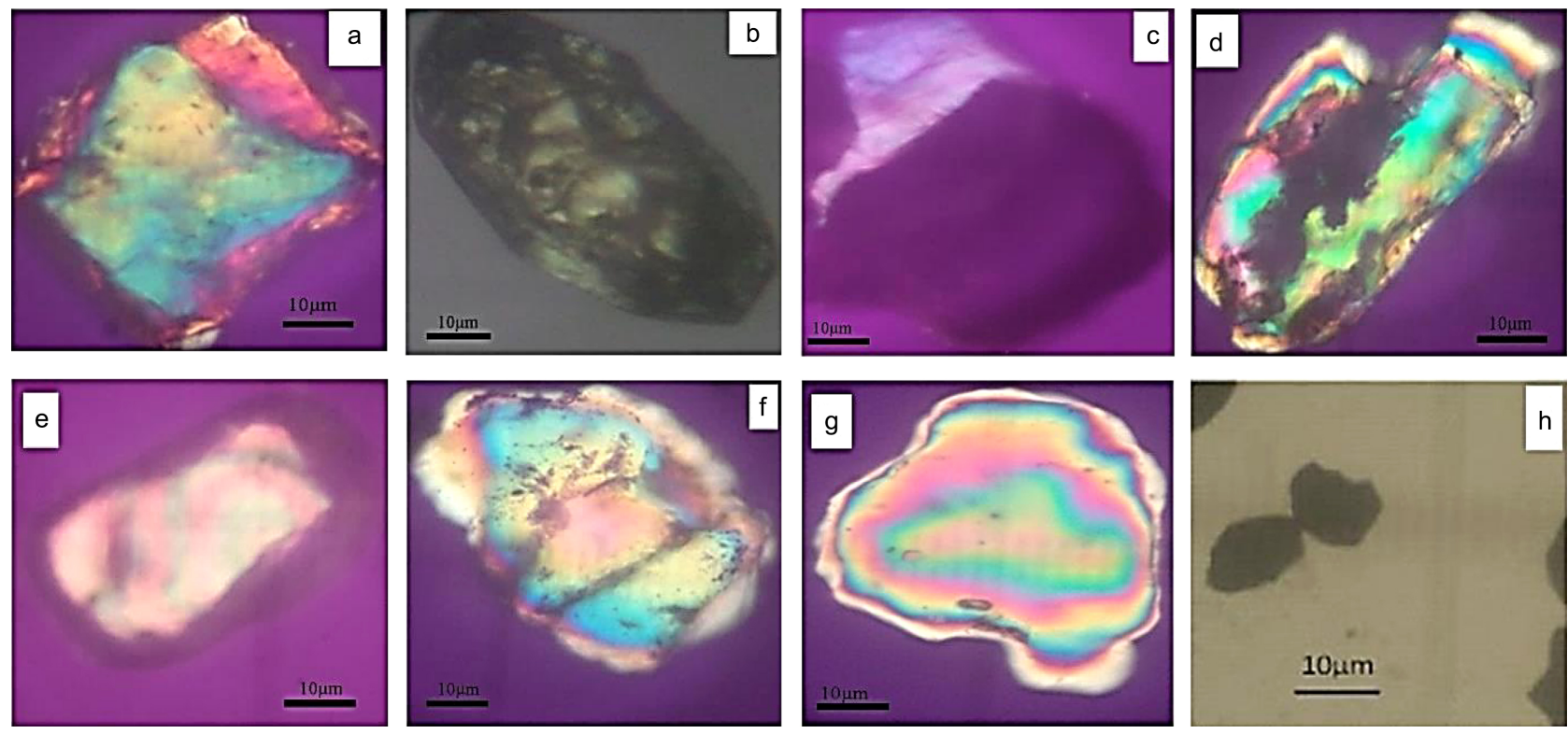

Figure 10. Heavy minerals with polarizing microscope. (a) Monazite; (b) Zircon; (c) Sphene; (d) Sillimanite; (e) Rutile; (f) Zoïsite; (g) Muscovite; (h) Opaque minerals. 

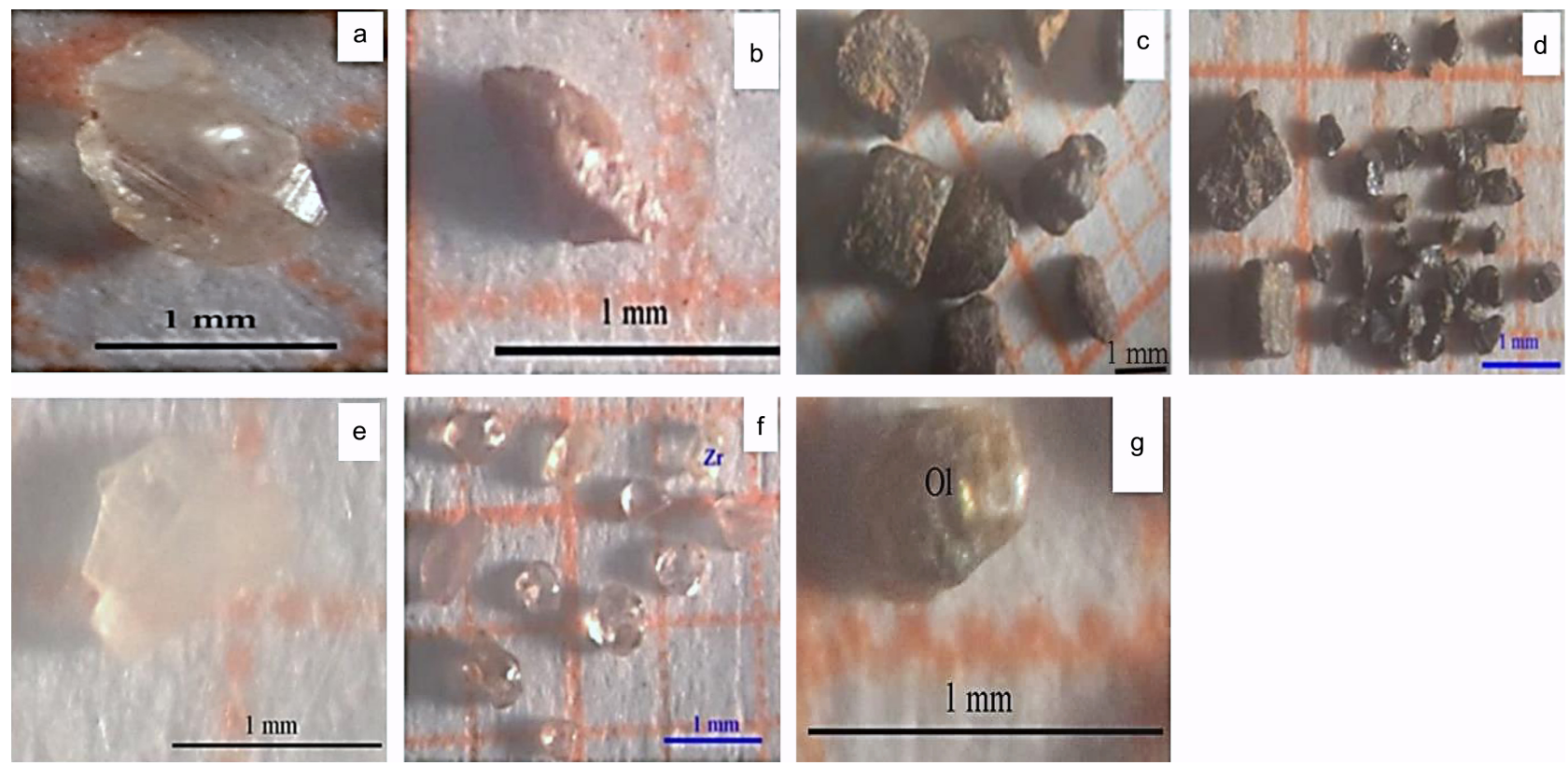

Figure 11. Heavy minerals with binocular magnifying glass. (a) Rutile; (b) Tourmaline; (c) Magnetite; (d) Ilmenite and hematite; (e) Kyanite; (f) Zircon; (g) Olivine.
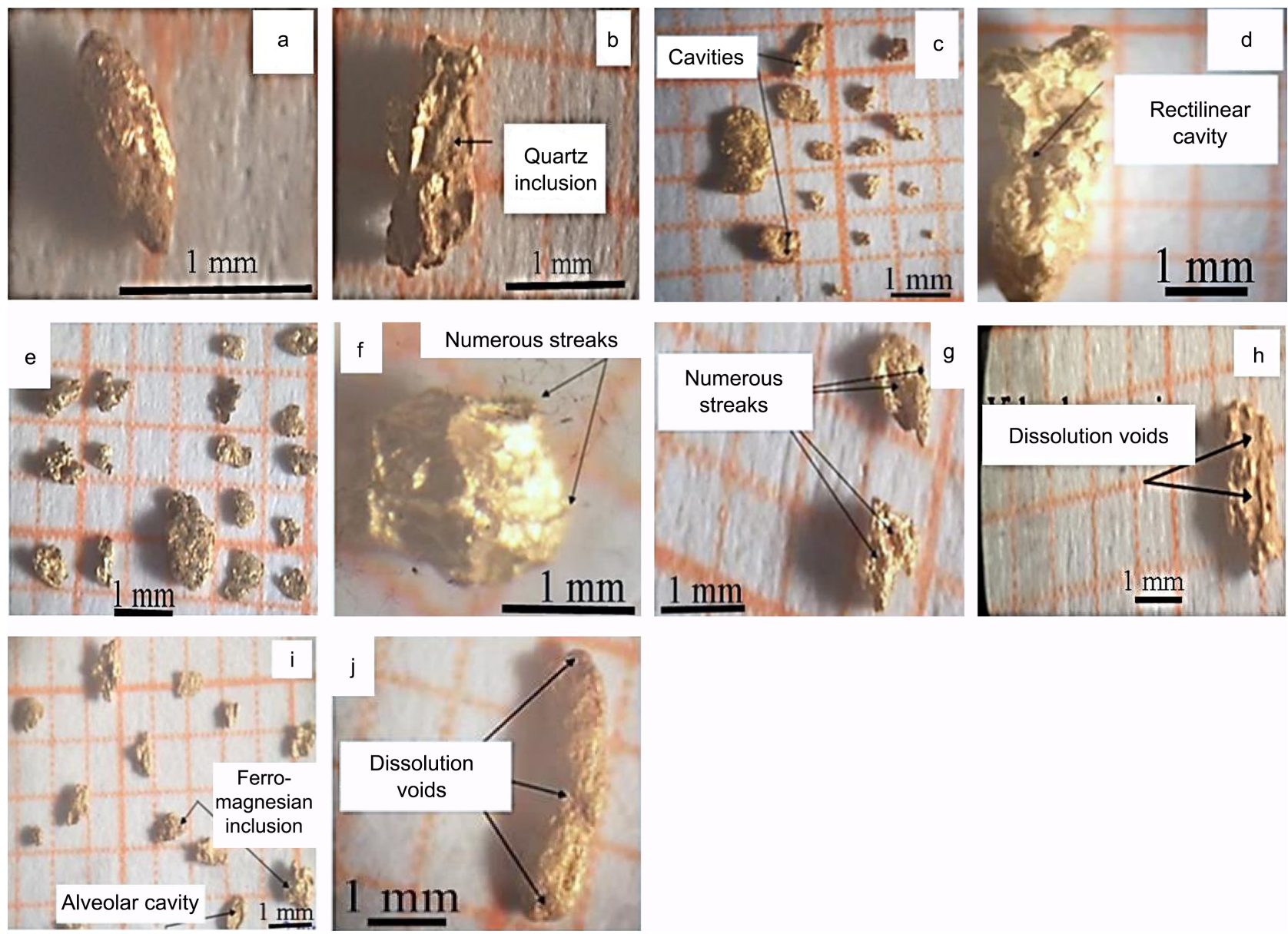

Figure 12. Gold grains observed with binocular magnifying glass; sample FEL 1 (a), (b); sample WAN 1 (c); sample GBA 1 (d), (e); sample GBA 2 (f), (g); sample LAW 1 (h), (i); sample KOM 1 (j). 
Sample FEL1 (Fel stream) has one blunt nugget and one striated angular nugget with quartz inclusion, medium bright. The flattening shows a short to medium distance to the source rock [43]. A total of 2 gold grains were obtained in the gravel of the river Fel having a weight of $0.05 \mathrm{~g}$.

Sample WAN 1 (Eluvium pit) has small glossy nuggets. The distance travelled by the grains is short to medium to the origin rock [43]. A total of 15 gold grains were obtained in the gravel horizon of the eluvium pit of Wan Tia having a weight of $0.08 \mathrm{~g}$.

Sample GBA1 (Aigbatoua stream) has a large, elongated, subdued, glossy nugget, small, moderately glossy blunt flakes, and small, subdued, slightly blunt nuggets. The distance travelled by the grains is medium [43]. A total of 18 gold grains were obtained in the gravel of the river Aigbatoua, having a weight of $0.13 \mathrm{~g}$.

Sample GBA2 (Sokour stream) has a very shiny, blunt rounded striated nugget, medium shiny subangular nuggets. The distance travelled is short [43]. A total of 3 gold grains were obtained in the gravel of river Sokour, with a weight of $0.02 \mathrm{~g}$.

Sample LAW1 (Mifek stream) has a blunt nugget with many medium glossy voids and small, shiny subblunt nuggets and shiny subblunt flakes. The distance to the bedrock is medium [43]. A total of 16 gold grains were obtained in the gravel of the river Mifek, having a weight of $0.1 \mathrm{~g}$.

Sample KOM 1 (WanToro stream) is a flattened, elongated, subemulsified, medium-glow straw. Its surface shows fine dissolution voids. The transport distance is quite long [43]. Only 1 gold grain was obtained in the gravel of the river Wan Toro, with a weight of $0.01 \mathrm{~g}$.

\subsection{Gold Grade Evaluation}

Data used in the evaluation of gold grade and results after the calculations are shown in Table 3. One used 40 liters $\left(0.04 \mathrm{~m}^{3}\right)$ of alluvium and 20 liters $(0.02$ $\left.\mathrm{m}^{3}\right)$ of eluvium horizon C. Calculations gave an average gold grade in gravel $\left(\mathrm{t}_{\mathrm{gr}}\right)$ of $0.65 \mathrm{mg} / \mathrm{m}^{3}$ and $0.4 \mathrm{mg} / \mathrm{m}^{3}$ in the excavated material $\left(\mathrm{t}_{\mathrm{e}}\right)$.

Table 3. Gold grade in gravel and excavated material.

\begin{tabular}{|c|c|c|c|c|c|c|c|c|}
\hline & W (g) & $\mathrm{N}\left(\mathrm{m}^{3}\right)$ & $\mathrm{n}$ & $\mathrm{t}_{\mathrm{gr}}\left(\mathrm{mg} / \mathrm{m}^{3}\right)$ & $\mathrm{g}(\mathrm{m})$ & $\mathrm{t}_{\mathrm{c}}\left(\mathrm{mg} / \mathrm{m}^{3}\right)$ & $\mathrm{s}(\mathrm{m})$ & $\mathrm{t}_{\mathrm{e}}\left(\mathrm{mg} / \mathrm{m}^{3}\right)$ \\
\hline FEL 1 & 0.05 & 0.04 & 4 & 0.5 & 0.5 & 0.25 & 0.45 & 0.26 \\
\hline WAN 1 & 0.08 & 0.02 & 2 & 0.8 & 0.4 & 0.32 & 0.35 & 0.7 \\
\hline GBA 1 & 0.13 & 0.04 & 4 & 1.3 & 0.3 & 0.39 & 0.25 & 0.71 \\
\hline GBA 2 & 0.02 & 0.04 & 4 & 0.2 & 0.45 & 0.09 & 0.40 & 0.11 \\
\hline LA W1 & 0.1 & 0.04 & 4 & 1 & 0.25 & 0.25 & 0.20 & 0.56 \\
\hline KOM 1 & 0.01 & 0.04 & 4 & 0.1 & 0.3 & 0.03 & 0.25 & 0.05 \\
\hline
\end{tabular}




\section{Discussion}

Studies on gold occurrences have already been the subject of numerous works carried out in the Intertropical zone, notably in Burkina Faso [44] [45] and in the humid tropics, precisely in Gabon [6] [46] [47] [48] [49], in Eastern and Southern Cameroon [9] [50]. Meiganga-East belongs to the central part of the pan-African chain in Cameroon. It also belongs to the Adamaoua basement consisting of metamorphic and granitoid rocks related to the Pan-African orogeny $(615 \pm 27$ to $652 \pm 10 \mathrm{Ma})$ or earlier $(880 \pm 55$ to $1008 \pm 65 \mathrm{Ma})$ [23]. The rocks encountered in the Meiganga locality are metamorphic (chloritoschist, schist bed quartzite, quartzite), magmatic (basalt, rhyolite) and sedimentary (conglomerate, argilites) rocks. The geological context is volcano-sedimentary with a slight metamorphism [31] [36]. The deformation phases in the Meiganga region are similar to those in the Foumban-Bankim region where [51] also highlights four deformation phases. In contrast, in the Banyo region [27] describes two Pan-African deformation phases.

In the East of Meiganga area, the alluvial materials studied by panning, are mostly those in the shallow beds of erosion potholes and to a lesser extent well potholes. Panning is widely used as a primary recovery method in the early days of mining. However, the process is extremely limited, as only coarse gold is recovered, while very fine particles are usually washed away with the gravel. Only small amounts of gravel can be processed, even by the most experienced panners. Today the gold pan is used mostly for prospecting or for cleaning concentrate. Its low price, immediate availability, and portability make it an essential tool for the prospector or miner [12]. The morphoscopy of the gold grains shows subangular to angular shapes. Some grains are porous with quartz encrustations. The size varies from 0.2 to $1.4 \mathrm{~mm}$ in diameter corresponding to dots and gold flakes. This implies that these gold grains would have undergone a short transport. This assumption is consistent with the qualification methods used by [38]. These different shapes observed on the gold particles may be a function of the distance travelled or the time taken in the river system [53]. Thus, the source of the gold is not far away (proximal source) and it would come from the rocks located upstream of the outcrops.

The areas (Fell, WanTia, Gbatoua, Lawan and Kombo Laka) where gold occurrences have been reported have a mineralogical suite consisting of zircon, tourmaline, kyanite, rutile, sphene, muscovite, monazite, sillimanite, zoite and opaque minerals. Zircon, tourmaline and monazite could be potential indicators and companions of gold [53] [54]. Gold is of all ages [5] [55]. It is found in the primitive, in the Precambrian granites of Campanha in Brazil, in the Huronian deposits interbedded in rocks (Alleghanis; Black Hills), in Itacolumies in Brazil; finally, it is found from this period in Nova Scotia, in Caledonia, in Siberia where the veins are encased in the Silurian. The Silurian formation contributed most to the formation of known gold deposits. In the Carboniferous, one finds the gold of New Brunswick's New Zealand. Zircon and tourmaline can be used 
tracers for lateritic materials [56]. The primary origin of heavy minerals will be much debated as some minerals are characteristic of several crystallization environments. This is the case of zircon, tourmaline and monazite which are minerals characteristic of magmatism but which can also crystallise in metamorphic rocks as gneiss. On the other hand, some are very specific to their deposition environments. Minerals such as kyanite and sillimanite are very characteristic of metamorphic rocks such as gneiss. Sphene crystallises in amphibole syenite [57] [58] [59] [60].

The SEM and X-ray diffractogram show clayey minerals (kaolinite, Illite) and non-clayey (Ilmenite, anatase, ...). These weathered products are different from those in the Nyong unit with pyroxenites and amphibolites [61]. The infrared spectrum of the sample shows on the vibrations of the $3800-3500 \mathrm{~cm}^{-1}$ region only three strong OH-links $\left(3692,3653,3620 \mathrm{~cm}^{-1}\right)$. A weak $3678 \mathrm{~cm}^{-1}$ bond, compared to $3652 \mathrm{~cm}^{-1}$, suggests low crystallinity of the kaolinite [62] [63]. Kaolinite is disorganized and weakly crystallized.

\section{Conclusion}

Meiganga-East is mineralized with alluvial/placer gold. The geologic formations of the area are low grade metamorphic rocks comprised of chloritoschist, quartzite with banded schist, and also olivine basalt, rhyolite, conglomerates, quartzite and argillites. With the action of weathering favored by the low crystallisation of sediment in the region, gold was liberated from the country rocks with their structural potential traps. Its presence in the alluvial system as secondary mineralization is accounted for by the erosion and transport of the weathered materials. The gold grains are less morphologically evolved; the similarity between the heavy mineral assemblage of eluvium and those of alluvium indicates probably that the alluvial gold originates from the weathering of neighboring country rocks. Average gold grade in gravel and in the excavated material indicate that the gold indices at Meiganga-East may be normal. The morphoscopic character of the gold (more or less spongy surface, reduced size, angular form) proves its weathering and mobilization in an alluvial environment.

\section{Acknowledgements}

The SEM, X-ray and infrared diffraction analyses were performed at the Research Unit Clay, Geochemistry and Sedimentary Environments (UR AGEs) of the University of Liège. We would like to thank them for their contribution to these results.

\section{Conflicts of Interest}

The authors declare no conflicts of interest.

\section{References}

[1] Chaussier, J.B. and Morer, J. (1981) Mining Prospector's Manual and Method. Edi- 
tions BRGM (Geological and Mining Research Office), No. 2 orleans, 273 p.

[2] Rudnick, R.L. and Gao, S. (2003) Composition of the Continental Crust. In: Rudnick, R.L., Ed., Treatise on Geochemistry, Elsevier, Amsterdam, 1-64.

https://doi.org/10.1016/B0-08-043751-6/03016-4

[3] Bierlein, F.P., Groves, D.I., Goldfarb, R.J. and Dubé, B. (2006) Lithospheric Controls on the Formation of Provinces Hosting Giant Orogenic Gold Deposits. Mineralium Deposita, 40, 874-886. https://doi.org/10.1007/s00126-005-0046-2

[4] Bierlein, F.P., Stein, H.J., Coira, B. and Reynolds, P. (2006) Timing of Gold and Crustal Evolution of the Palaeozoic South Central Andes, NW Argentina Implications for the Endowment of Orogenic Belts. Earth and Planetary Science Letters, 245, 702-721. https://doi.org/10.1016/j.epsl.2006.03.019

[5] Frimmel, H.E. (2008) Earth's Continental Crustal Gold Endowment. Earth and Planetary Science Letters, 267, 45-55. https://doi.org/10.1016/j.epsl.2007.11.022

[6] Colin, F. and Lecomte, P. (1988) Mineralogical and Chemical Study of the Alteration Profile of the Gold Prospect of Mbanga Mvomo (Gabon). Chronique de la recherche minière, 491, 55-65.

[7] Asaah, A.V. (2010) Lode Gold Mineralization in the Neoproterozoic Granitoids of Batouri, Southeastern Cameroon. PhD Dissertation Doctorate, Technische Universität Clausthal, Clausthal-Zellerfeld, 187 p.

[8] Vishiti, A., Suh, C.E., Lehmann, B., Egbe, J.A. and Shemang, E.M. (2015) Gold Grade Variation and Particle Microchemistry in Exploration Pits of the Batouri Gold District, SE Cameroon. Journal of African Earth Sciences, 111, 1-13. https://doi.org/10.1016/j.jafrearsci.2015.07.010

[9] Suh, C.E., Lehmann, B. and Mafany, G.T. (2006) Geology and Geochemical Aspects of Gold Mineralization at Dimako-Mboscorro SE Cameroon. Geochemistry Exploration Environment Analysis, 6, 295-309. https://doi.org/10.1144/1467-7873/06-110

[10] Embui, V.F., Omang, B.O., Che, V.B., Nforba, M.T. and Suh, E.C. (2013) Gold Grade Variation and Stream Sediment Geochemistry of the Vaimba-Lidi Drainage System, Northern Cameroon (West Africa). Natural Science, 5, 282-290. https://doi.org/10.4236/ns.2013.52A040

[11] Tchameni, R., Doumang, J.C., Deudibaye, M. and Branquet, Y. (2013) Occurrence of Gold Mineralization in the Pala Neoproterozoic Formations South-Western Chad. Journal of African Earth Sciences, 84, 36-46. https://doi.org/10.1016/j.jafrearsci.2013.03.002

[12] Silva, M. (1986) Placer Gold Recovery Methods. California Department of Conservation Division of Mines and Geology. Special Publication 87.

[13] Manga, V.E., Neba, G.N. and Suh, C.E. (2017) Environmental Geochemistry of Mine Tailings Soils in the Artisanal Gold Mining District of Bétaré-Oya Cameroon. Environment Pollution, 6, 52-61. https://doi.org/10.5539/ep.v6n1p52

[14] Vishiti, A., Suh, C., Lehmann, B., Shemang, E.M., Ngome, N.L.J., Nshanji, N.J., Chinjo, F.E., Mongwe, O.Y., Egbe, A.J. and Petersen, S. (2017) Mineral Chemistry, Bulk Rock Geochemistry, and S-Isotope Signature of Lode Gold Mineralization in Betaré-Oya District, South-East Cameroon. Wiley Geological Journal, 53, 2579-2596. https://doi.org/10.1002/gj.3093

[15] https://www.Cameroonminingcadastralportal.com

[16] Eno Belinga, S.M. (1972) Alteration of Basaltic Rocks and the Bauxitization Process in Adamawa Region (Cameroon). Doctorate Thesis, University of Paris VI, Paris, 
$571 \mathrm{p}$.

[17] Temdjim, R. (2005) Contribution to the Knowledge of the Upper Material of Cameroon through the Study of the Ultrabasic and Basic Enclaves Raised by the Volcanoes of Youkou Adamawa and Nyos (Cameroon Line). Doctorate Thesis, University of Yaoundé I, Yaoundé, $346 \mathrm{p}$.

[18] Nkouandou, O.F., Ngounouno, I. and Deruelle, B. (2010) Geochemistry of Recent Basaltic Lavas from the Northern and Eastern Areas of Ngaoundéré (Cameroon, Adamawa Plateau, Central Africa) Petrogenesis and Nature of the Source. The International Journal of Biological and Chemical Sciences, 4, 984-1003.

[19] Dorbath, L., Dorbath, C., Stuart, G. and Fairhead, D. (1984) Structure of the Crust under the Adamawa Plateau (Cameroon). Comptes Rendus Academie Sciences, 12, 539-542.

[20] Tchoua, F. (1997) Cretaceous Attribution of the Metamorphic Conglomerate of Adamawa (Cameroon). Faculty of Sciences Review, Yaoundé, 69-76.

[21] Tchatchoua, S.M., Njiké Ngaha, P.R., Salah, M.M., Said, D.A. and Ekodeck, E.G. (2010) Existence of "Late Continental" Deposits in the Mbere and Djerem Sedimentary Basins (North Cameroon) Palynologic and Stratigraphic Evidence. Journal of Geology and Mining Research, 6, 159-169.

[22] Nzenti, J.P. (1994) Pan-African Adamawa (Banyo Region) a Key Area for Geodynamic Model of the North Equatorial Pan-African Range in Cameroon. Doctorate Thesis, Université Cheikh-Anta-Diop University of Nancy I, Nancy, 176 p.

[23] Tchameni, R., Pouclet, A., Penaye, J., Ganwa, A.A. and Toteu, S.F. (2006) Petrography and Geochemistry of the Ngaoundéré Pan-African Granitoïds in Central Nord-Cameroon Implication for Their Sources and Geological Setting. Journal of African Earth Sciences, 44, 511-529. https://doi.org/10.1016/j.jafrearsci.2005.11.017

[24] Toteu, S.F., Van Schmus, R.W., Penaye, J. and Michard, A. (2001) New U-Pb and Sm-Nd Data from North-Central Cameroon and Its Bearing on the Pre-Pan-African History of Central Africa. Precambrian Research, 108, 45-73. https://doi.org/10.1016/S0301-9268(00)00149-2

[25] Ganwa, A.A., Siebel, W., Frisch, W., Kongnyuy and Shang, C. (2011) Geochemistry of Magmatic Rocks and Time Constraints on Deformational Phases and Shear Zone Slip in the Méiganga Area Central Cameroon. International Geology Review, 53, 759-784. https://doi.org/10.1080/00206810903211161

[26] Ganwa, A.A., Siebel, W., Kongnyuy Shang, C., Seguem, N. and Ekodeck, G.E. (2011) New Constraints from Pb-Evaporation Zircon Ages of the Méiganga Amphibole-Biotite Gneiss Central Cameroon on Proterozoic Crustal Evolution. International Journal of Geosciences, 2, 138-147. https://doi.org/10.4236/ijg.2011.22014

[27] Nzenti, J.P., Barbey, P., Bertrand, J.M. and Macaudière, J. (1994) Pan-African Chain Cameroon: Looking for Suture and Model. Abstracts 15th RST, Nancy, Geological society of France, Edition Paris, 99.

[28] Kankeu, B. (2008) Anisotropy of Magnetic Susceptibility (AMS) and Manufactures Neoproterozoic Rocks from the Regions of Garga-Sarli and Bétaré-Oya from the East of Cameroon Geodynamic Implications for the Evolution of the Pan-African Chain in Central Africa. Doctoral Thesis, University of Yaoundé I, Yaoundé, 159 p.

[29] Lasserre, M. (1961) Reconnaissance Geological Map to Scale 1/500.000 Cameroon Territory Ngaoundéré-East. Direction of Mining and Geology, Yaoundé.

[30] Njiosseu Tanko, E.L., Nzenti, J.P., Njanko, B., Kapajika, B. and Nedelec, A. (2005) New U-Pb Zircon Ages from Tonga (Cameroon) Coexisting Eburnean Transama- 
zonian $(2.1 \mathrm{Ga})$ and Pan-African $(0.6 \mathrm{Ga})$ Imprints. Comptes rendus Academie Sciences, 337, 551-562. https://doi.org/10.1016/j.crte.2005.02.005

[31] Soba, D. (1989) The Lom Series: Geological and Geochronological Study of a Volcanic-Sedimentary Basin of the Pan-African Chain in Eastern Cameroon. Doctorate Thesis, University of Pierre et Marie Curie, Paris, 198 p.

[32] Bisso, D., Manguelle-Dicoum, E., Ndougssa Mbarga, T., Tabod, C.T., Njanjock, N.P., Njingti, N., Tadjou, J.M. and Essono, J. (2004) Geophysical Determination of the Sanaga Fault Using Audio-Magnetotelluric Sounding in the Ebebda Region, Cameroon. SEGMITE International, 1, 31-34.

[33] Ngako, V. (1999) Pan-African Continental Deformations in Central Africa: Result of a Himalayan Type Punching. Doctorate Thesis, University of Yaoundé I, Yaoundé, $241 \mathrm{p}$.

[34] Baise, D. (1995) Guide to the Description Soils. National Institute for Agricultural Research (NIAR), Paris. (In French)

[35] Diguim Kepnamou, A. (2011) Petrographic and Structural Study of Kalaldi Badzer Southwest of Meiganga (Centre Cameroon). Master Thesis, University of Ngaoundéré, Ngaoundéré, 71 p.

[36] Ganwa, A.A. (2005) The Granitoids of Meiganga: Petrographic, Geochemical, Structural and Geochronological Study Their Place in the Pan-African Chain. Postgraduate Thesis, University of Yaoundé I, Yaoundé, 162 p.

[37] Gary, N. (2009) Sedimentology and Stratigraphy. 2nd Edition, Wiley, Hoboken, 397 p.

[38] Cailleux, A. (1942) Periglacial Wind Actions in Europe. Memorandum of the Geological Society of France, XXI, fasc. 1-2, 176 p.

[39] Berthois, L. (1975) Sedimentological Study of Loose Rocks (Techniques and Methods). Doin Publisher, Paris, 277 p.

[40] Beaux, J.F., Fogelgesang, J.F., Agard, P. and Boutin, V. (2011) Geology and Petrology Atlas. Dunod, Paris, 143 p.

[41] Sobgwi, E. (2005) Contribution to the Physico-Chemical and Mineralogical Study of the Materials of the Clay Deposit of Mayouom Case of the Materials in Well Number 1. Master Thesis, University of Yaoundé I, Yaoundé, $60 \mathrm{p}$.

[42] Worrall, W.E. (1986) Clays and Ceramic Raw Materials. Applied Sciences, 2, 117-203.

[43] Herail, G., Fornari, M., Miranda, V. and Viscarra, G. (1988) Discovery of New Primary Gold Mineralizations in the Cordillera Royale of Bolivia from the Morphoscopic Analysis of Gold Flakes Taken from Alluvium. Comptes Rendus de P Académie des Sciences Paris, 307, 63-69.

[44] Parisot, J.C., Ventose, V., Grandin, G., Bourges, F., Debat, P., Tollon, F. and Millo, L. (1995) Dynamics of Gold and Other Heavy Minerals in the Burkina Faso Weathering Profile, West Africa Interest for the Interpretation of the Setting of Minerals Constituting the High Glacis Armour. Comptes Rendus Academie Sciences, 321, 295-302.

[45] Bamba, O., Beziat, O., Bourges, E., Debat, P., Lompo, M., Parisot, C., Tollon, F. and Halpin, C. (1996) New Type of Gold Deposit in the Birrimian Greenstone Belts of Burkina Faso. Journal of African Earth Sciences, 124, 307-316.

[46] Edou Minko, A. (1988) Petrology and Geochemistry of Laterites from Stonelines of Ovala Gold Deposit Application to Prospecting in the Humid Equatorial Zone (Gabon). Doctorate Thesis, University of Poitiers, Poitiers, 147 p. 
[47] Colin, F., Boulangé, B. and Lecomte, P. (1989) Dissolution Features of Gold Particles in Lateritic Profile from Dondo Mobi Gabon. Geoderma, 45, 241-250. https://doi.org/10.1016/0016-7061(89)90009-8

[48] Edou Minko, A., Colin, F., Lecomte, P. and Trescases, J.J. (1992) Lateritic Alteration of the Ovala Gold Deposit (Gabon) and Formation of a Surface Dispersion Anomaly. Mineralium Deposita, 25, 90-100.

[49] Colin, F., Viellard, P. and Ambrosi, J.P. (1993) Behaviour of Gold in Lateritic Equatorial Environment Mass Balance Transfer and Thermodynamic Study. Earth and Planetary Sciences Letters, 114, 269-285. https://doi.org/10.1016/0012-821X(93)90030-D

[50] Suh, C.E. and Lehmann, B. (2003) Morphology and Electron-Probe Microanalysis of Residual Gold Grains at Dimako South East Cameroon. Neues Jahrbuch für Mineralogie-Monatshefte, 6, 255-275. https://doi.org/10.1127/0028-3649/2003/2003-0255

[51] Njonfang, E. (1998) Contribution to the Study of the Relationship between the Cameroon Line and the Adamawa Direction 1) Petrography, Geochemistry and Structural of Pan-African Granitoids of the Shear Zone Foumban-Bankim (West Cameroon and Adamawa) 2) Petrology and Geochemistry of the Associated Tertiary Formations. Doctorate Thesis, University of Yaoundé I, Yaoundé, 392 p.

[52] Youngson, J. and Craw, D. (1999) Variation in Placer Style, Gold Morphology, and Gold Particle Behavious Down Gravel Bed-Load Rivers: An Example from the Shotover/Arrow Kawarau-Clutha River System, Otago, New Zealand. Economic Geology, 94, 615-634. https://doi.org/10.2113/gsecongeo.94.5.615

[53] Béziat, D., Dubois, M., Debat, P., Nikiéma, S., Salvi, S. and Tollon, F. (2007) Gold Metallogeny in the Birimian Craton of Burkina Faso (West Africa). Journal of African Earth Sciences, 50, 215-233. https://doi.org/10.1016/j.jafrearsci.2007.09.017

[54] Fuanya, C., Yongué Fouateu, R. and Kankeu, B. (2014) Geological Study of Gold Indices at Ako'Azam Akom II Region (South Cameroon). Sciences Technologies et Developpement, 15, 98-106.

[55] Frimmel, H.E. (2018) Episodic Concentration of Gold to Ore Grade through Earth's History. Earth and Science Reviews, 180, 148-158. https://doi.org/10.1016/j.earscirev.2018.03.011

[56] Ouangraw, M. and Yongue Fouateu, R. (2001) Gold, Zircon and Tourmaline Tracers of the Origin of Lateritic Profile Materials in Africa. African Journal of Science and Technology Science and Engineering, 2, 25-40.

[57] Duplaix, S. (1958) Microscopic Determination of Sand Minerals. Revised 2nd Edition, Ch. Beranger, Paris, $571 \mathrm{p}$.

[58] Parfenoff, A., Pomerol, C. and Tourenq, J. (1970) Grain Minerals, Study Method and Determination. Masson \& Cie, Paris, $571 \mathrm{p}$.

[59] Pellant, C. (1994) Rocks and Minerals: The Visual Guide to More than 500 Rock and Mineral Specimens around the World. Rocks and Minerals (Eyewitness Handbooks). $256 \mathrm{p}$.

[60] Foucault, A. and Raoult, F. (2001) Geology Dictionary. 5th Edition, Penguin, New York, $380 \mathrm{p}$.

[61] Ebah Abeng, S.A., Ndjigui, P.D., Beyanu, A.A., Teutsong, T. and Bilong, P. (2012) Geochemistry of Pyroxenites, Amphibolites and Their Weathered Products in the Nyong Unit, SW Cameroon (NW Border of Congo Craton) Implications for Au-PGE Exploration. Journal of Geochemical Exploration, 114, 1-19. https://doi.org/10.1016/j.gexplo.2011.11.003 
[62] Cases, J.M., Lietard, O., Yvon, J. and Delon, J.F. (1982) Study of the Crystallochemical and Surface Morphological Properties of Disorganised Kaolinite. Mineralogy Bulletin, 105, 439-455. https://doi.org/10.3406/bulmi.1982.7566

[63] Ngon Ngon, G.F., Yongue-Fouateu, R., Bitom, D.L. and Bilong, P. (2009) A Geological Study of Clayey Laterite and Clayey Hydromorphic Material of the Region of Yaoundé (Cameroon) a Prerequisite for a Local Material Promotion. Journal of African Earth Science, 55, 69-78. https://doi.org/10.1016/j.jafrearsci.2008.12.008 